\title{
フローサイトメリリー解析による除草剤の 微細藻類細胞に対する影響評価
}

\author{
石原 悟 ${ }^{*}$. 堀尾 剛 $^{*}$. 小原裕三 ${ }^{*}$. 横山淳史 ${ }^{*}$
}

\begin{abstract}
要 約: 除草剂が 3 種の微細藻類 (Pseudokirchneriella subcapitata, Achnanthidium minutissimum 及び Merismopedia tenuissima）細胞の形態に及ぼ す影響を, 光学顕微鏡による観察と, フローサイトメー ターで側方散乱光強度（Side Scatter 強度, 以下 $\mathrm{SSC}$ 強度という）及びクロロフィル a の自家蛍光強度 (Autonomous Fluorescence, $610 \mathrm{~nm}$; 以下 $\mathrm{AF}_{610}$ 強 度という）を測定した結果から評価した。これらの藻 類のうち細胞の形態変化が最も顕著に観察されたの は, 緑藻 P. subcapitataであった。細胞のドットプロット が示す特徵から, 40 種類の除草剤がP. subcapitata 細胞の形態に及ぼす影響を 4 型（Type A-D）に類 型化した。さらに, 7 種類の除草剤（エスプロカルブ, キノクラミン, シメトリン, チオベンカルブ, プレチラクロー ル, ベンスルフロンメチル, メフェナセット）を, $\mathrm{EC}_{50}(50 \%$
\end{abstract} Effective Concentration）の $6 \sim 12$ 倍の濃度で 72 時間暴露した後, 13 日間再培養を続け, 形態が変化 した細胞の回復性を調べた。その結果, すべての除 草剂暴露区に関して, 除草剤による影響からの回復が 確認された。形態変化を類型別に評価すると, $\mathrm{AF}_{610}$ 強度の低下した細胞（白化した細胞）が多く観察さ れる個体群で回復までの期間が長い傾向が示された。

藻類生長阻害試験に打ける細胞観察にフローサイト メーターを用い, $\mathrm{SSC}$ 及び $\mathrm{AF}_{610}$ 強度を測定することで, 細胞の形態に及ぼす影響及び回復性を考慮した除草 剤の影響評価が可能である。

キーワード: 除草剤, フローサイトメトリー, 藻類, 形態 変化, 回復性, 生態肖ク評価

\section{緒言}

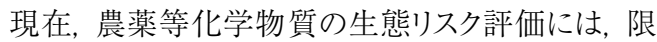
られた生物種における実験室レベルの試験結果

*独立行政法人農業環境技術研究所 $\bar{T} 305-8604$ 茨城 県つくば市観音台 3-1-3 satorui@niaes.affrc.go.jp

(2006 年 6 月 16 日受付, 2006 年 9 月 19 日受理)
が利用されている。水生一次生産者に対する影 響評価に関しては, 初期段階の評価で淡水産浮 遊性単細胞緑藻に対する生長阻害試験の結果が 利用されている。影響評価指標には, $\mathrm{EC}_{50}(50 \%$ Effective Concentration), NOEC (No Observed Effect Concentration), LOEC (Lowest Observed Effect Concentration）等の毒性值が用いられる ${ }^{10,14,22)}$ 。藻類 生長阻害試験に関する各種指針では, 試験終了時に おける細胞形態の観察結果を毒性值と共に報告する ことを求めている。しかし, 微細藻類の大きさは, 直径 が 10〜20 $\mu \mathrm{m}$ 程度であり, 形態の変化を光学顕微 鏡による観察で評価することは難しい。そのため, 生 長阻害下の藻類細胞の形態については詳細を検討さ れないことが多い。また，化学物質による影響からの 回復性は, 個体群へ及ぼす影響を推測する上で重要 な情報であるにもかかわらず，的確に評価がされてい ないのが現状である。

フローサイトメーターを用いた細胞の計測手法では, 試料中に含まれる細胞一つずつの大きさ, 形状, 内部 構造等を散乱光や蛍光強度の数值で測定し, ヒストグ ラムを作図することにより細胞群集の形態を比較するこ とが可能である。そのためフローサイトメトリーは生命 工学や臨床検査などの分野で重要な役割を担う技術 となっている ${ }^{11)}$ 。また近年では, 微細藻類が発する赤 色自家蛍光を測定する技術を応用した, ピコプランクトン

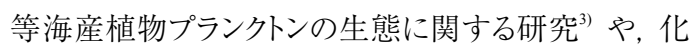
学物質の藻類に対する影響評価への利用も進められ ている2,6,7,19,21)。

有害物質による微細藻類細胞の形態変化につい ては, トリアジン系及びフェニルウレア系除草剤の暴露 による緑藻 Chlorella vulugaris細胞の肥大化 ${ }^{16}$, 殺 虫剤メチルパラチオンの暴露による緑藻 Chlorella protothecoides 細胞の肥大化 ${ }^{17}$, 銅の暴露による珪藻 Phaeodactylum tricornutum細胞の肥大化及び自家 蛍光強度の増加 ${ }^{4,15}$ 等の報告があるものの, 作用機構 との関連を比較·考察した研究は少ない。

本研究では, 40 種類の除草剂を用い, 生長阻害下 
の緑藻 P. subcapitata細胞について, フローサイトメー ターで $\mathrm{SSC}$ 及び $\mathrm{AF}_{610}$ 強度を計測し, ドットプロットを作 図した。各ドットプロッの特徵から, 除草剤が藻類細 胞の形態に及ぼす影響を類型化した。さらに, 7 種類 の除草剂について, 生長阻害下のP. subcapitata細 胞を, 除草剤を含まない培地で再度培養し, 生長速 度, ドットプロット及び細胞形態を対照区と比較して, $P$. subcapitata細胞の除草剂による影響からの回復性を 形態及び生長速度の面から評価した。

\section{材料及び方法}

\section{1. 試験生物}

除草剂の影響による形態変化の類型化には, 綱の 異なる 3 種の淡水産単細胞藻類Pseudokirchneriella subcapitata ATCC22662（緑藻綱）, Merismopedia tenuissima NIES-230（藍藻綱）及び Achnanthidium minutissimum NIES-71（珪藻綱）を用いた。除草 剤による影響からの回復性の検討は, P. subcapitata についてのみ行った。試験に使用した藻類株は, $P$. subcapitataについてはATCC (American Type Culture Collection）より, その他 2 種については財団 法人地球・環境フォーラム（現独立行政法人国立環 境研究所・環境研究基盤技術ラボラトリー）より分与 された株を使用した。

\section{2. 試験生物の培養条件}

前培養及び試験には, P. subcapitata及び M. tenuissimaについては C 培地 ${ }^{23}$ を使用し, $A$. minutissimumについてはCsi 培地 ${ }^{23)}$ の緩衝剂を HEPES から Tris-HCl, pHを 7.0 から 7.5 に改変して 使用した。継代培養には両培地の寒天培地 $(1.5 \%)$ を用いた。培養条件は白色蛍光灯による上部照明で 照度約 4,000 lux, 連続照明, 温度 $23 \pm 2^{\circ} \mathrm{C}$ とた。

\section{3. 試験に用いた除草剤}

試験に用いた 40 種類の除草剤を HRAC（Herbicide Resistance Action Committee）による作用機 構の分類に基づいて水溶解度と共に第 1 表に示し た。使用した除草剤は日本において農薬の登録があ るもの，もしくは過去に登録されていたものから水稲用 除草剤を中心に選択した。試験にはすべての除草剂 について分析用標準品を使用した。

\section{4. 生長阻害率及び形態変化の類型化に関する試験}

各除草剤 $1 \mathrm{mg}$ を秤量し, $100 \mu \mathrm{l}$ のアセトンに溶解 した。このアセトン溶液 $30 \mu \mathrm{l}$ を $50 \mathrm{ml}$ 三角フラスコ中 の液体培地 $30 \mathrm{ml}$ に懸濁し, 試験溶液 $\left(10 \mathrm{mg}^{-1}\right.$ 溶
液）を作成した。ここに試験生物を接種し，試験開始 とした。水溶解度が $10 \mathrm{mg} \mathrm{l}^{-1}$ 以下である除草剤につ いては, 培養液中に被検物質の沈殿を生じたが, 沈 殿物がある状態（飽和状態）で暴露を行った。いず れの試験も前培養を 72 時間行い対数増殖期にある 細胞を接種した。初期細胞密度は P. subcapitata, $M$. tenuissima及び A. minutissimumそれぞれについて 5 $\times 10^{4}, 3 \times 10^{4}, 1 \times 10^{4}$ cells ml ${ }^{-1}$ とし, 暴露を 72 時間 行った。暴露終了後にフローサイトメーター（PAS flow cytometer, partec $\mathrm{GmbH}$ ) を用いて細胞数を計測し, 対照区（溶媒対照区 = アセトン $1,000 \mathrm{mg} \mathrm{l}^{-1}$ ) の細胞 数と比較した。生長阻害率は面積法により算出した。 形態変化の類型化には, フローサイトメーターを用いて $\mathrm{SSC}$ 及び $\mathrm{AF}_{610}$ 強度を測定し, ドップロット及びヒストグ ラム（第 1 図）を作図すると共に, 試験溶液を一部取 り出し正立顕微鏡により明視野及び蛍光観察（共に 400 倍) を行い, 観察試料中の藻類細胞の肥大及び 白化を観察した。 $\mathrm{SSC}$ 及び $\mathrm{AF}_{610}$ 強度のヒストグラム については，それぞれの平均值をフローサイトメーター 附属のソフト（partec, FloMax ver. 2.0）を用いて求め, 対照区の平均值と比較した。

なお, SSC は光軸に対して 90 度の位置で検出する 光であり, 細胞の顆粒や細胞内構造の状態に散乱光 強度が関連しているとされている。SSC 強度の值が相 対的に大きいことは細胞の内部構造が複雑であること を示し, SSC 強度の值が小さければ細胞の内部構造 は単純であると考えられている。P. subcapitata細胞の 場合, SSC 強度は細胞の大きさとよく対応する。一方, $\mathrm{AF}_{610}$ 強度は一般に細胞内のクロロフィル $\mathrm{a}$ 含量と比例 すると考えられており, 相対的に $\mathrm{AF}_{610}$ 強度の值が小さ ければ細胞のクロロフィル $\mathrm{a}$ 含量が少ない傾向にある と考えられる。但し, $\mathrm{AF}_{610}$ 強度については, 高温条件 下で植物細胞の自家蛍光強度が上昇するとの報告も あり ${ }^{18)}$, ストレス条件下においては単純にクロロフイル a 含量と比例するものではない。

\section{5. 除草剤による影響からの回復性に関する試験}

除草剂の暴露により一時的に生長が阻害され, 形 態が変化したP. subcapitata細胞の除草剂による影響 からの回復性を, 7 種類の除草剤（エスプロカルブ, キノクラミン, シメトリン, チオベンカルブ, プレチラクロー ル, ベンスルフロンメチル, メフェナセット）について調 べた。試験は 3 連で行い, 試験容器として $300 \mathrm{ml}$ の 三角フラスコを用い, 培地量は $100 \mathrm{ml}$ とした。暴露濃 度は各除草剤における面積法により算出した $\mathrm{EC}_{50}$ の 6 
第 1 表 試験に使用した除草剂の作用機構と水溶解度及び $10 \mathrm{mg}^{-1}$ もしは飽和濃度で 72 時間暴露した 3 種藻類 (P. subcapitata, M. tenuissima 及び A. minutissimum) の生長阻害率

\begin{tabular}{|c|c|c|c|c|c|c|}
\hline $\begin{array}{l}\text { HRAC } \\
\text { Group }\end{array}$ & 作用機構 & 除草剂名 & $\begin{array}{c}\text { 水溶解度 }{ }^{*} \\
\left(\mathrm{mg} \mathrm{l}^{-1}\right)\end{array}$ & P. subcapitata & $\begin{array}{l}\text { 生長阻害率 * } \\
\text { M. tenuissima }\end{array}$ & A. minutissimum \\
\hline $\mathrm{A}$ & $\mathrm{ACC}^{1)}$ & シハロホップブチル & 0.40 & - & ++ & ++ \\
\hline \multirow[t]{4}{*}{$\mathrm{B}$} & $\mathrm{ALS}^{2)}$ & アジムスルフロン & 1100 & ++++ & ++++ & ++ \\
\hline & & イマゾスルフロン & 310 & ++++ & ++++ & - \\
\hline & & ピラゾスルフロンエチル & 10 & ++++ & ++++ & - \\
\hline & & ベンスルフロンメチル & 120 & ++++ & ++++ & - \\
\hline \multirow[t]{6}{*}{$\mathrm{C} 1$} & PS $I^{3)}$ & アトラジン & 33 & ++++ & ++++ & ++++ \\
\hline & & シアナジン & 170 & ++++ & ++++ & ++++ \\
\hline & & シマジン ～～～～～～～～ & 6.2 & ++++ & ++++ & ++++ \\
\hline & & ジメタメトリン & 50 & ++++ & ++++ & ++++ \\
\hline & & シメトリン & 400 & ++++ & ++++ & ++++ \\
\hline & & プロメトリン & 33 & ++++ & ++++ & ++++ \\
\hline \multirow[t]{3}{*}{$\mathrm{C} 2$} & & ジウロン & 36 & ++++ & ++++ & ++++ \\
\hline & & プロパニル & 130 & ++++ & ++++ & ++++ \\
\hline & & リニュロン & 64 & ++++ & ++++ & ++++ \\
\hline $\mathrm{C} 3$ & & ベンタゾン & 570 & - & ++++ & - \\
\hline $\mathrm{D}$ & PS I I) $^{4}$ & ジクワット & 700000 & ++++ & ++++ & ++++ \\
\hline \multirow[t]{3}{*}{$\mathrm{E}$} & $\mathrm{PPO}^{5)}$ & オキサジアゾン & 1.0 & ++++ & ++++ & ++++ \\
\hline & & ビフェノックス & 0.35 & ++++ & ++++ & ++++ \\
\hline & & ペントキサゾン & 0.22 & ++++ & ++++ & ++++ \\
\hline \multirow[t]{2}{*}{$\mathrm{F} 2$} & $\mathrm{HPPD}^{6}$ & ピラゾキシフェン & $0.80^{\# \#}$ & ++++ & ++++ & ++++ \\
\hline & & ピラゾレート & 0.056 & ++++ & ++++ & ++++ \\
\hline \multirow[t]{3}{*}{$\mathrm{K} 1$} & Microtubule ${ }^{7}$ & アミプロホスメチル & $20^{\# \# \#}$ & ++++ & ++++ & ++++ \\
\hline & & トリフルラリン & 0.22 & ++++ & ++++ & + \\
\hline & & ペンディメタリン & 0.30 & ++++ & ++++ & ++++ \\
\hline \multirow[t]{6}{*}{$\mathrm{K} 3$} & VLCFAs $^{8)}$ & アラクロール & 170 & ++++ & + & ++++ \\
\hline & & カフェンストロール & 2.5 & ++++ & ++ & ++++ \\
\hline & & ピペロホス & 25 & ++++ & + & ++++ \\
\hline & & プレチラクロール & 50 & ++++ & ++++ & ++++ \\
\hline & & メトラクロール & 490 & ++++ & - & +++ \\
\hline & & メフェナセット & 4.0 & ++++ & + & ++++ \\
\hline \multirow[t]{5}{*}{$\mathrm{N}$} & Lipid $^{9}$ & エスプロカルブ & 4.9 & ++++ & ++++ & ++++ \\
\hline & & ジメピペレート & 20 & ++++ & +++ & ++++ \\
\hline & & ベンスリド & 25 & ++++ & ++++ & ++++ \\
\hline & & チオベンカルブ & 30 & ++++ & ++++ & ++ \\
\hline & & モリネート & 900 & ++++ & ++++ & ++++ \\
\hline $\mathrm{O}$ & Auxins $^{10)}$ & ジカンバ & 6100 & - & + & - \\
\hline \multirow[t]{2}{*}{$\mathrm{Z}$} & Unknown & ダイムロン & 1.2 & + & - & - \\
\hline & & ピリブチカルブ & 0.32 & ++++ & ++++ & + \\
\hline- & PS II or PPO & キノクラミン & $22^{\# \#}$ & ++++ & ++++ & ++++ \\
\hline- & $\mathrm{OP}^{11) \ldots}$ & ペンタクロロフェノール & 80 & ++++ & ++++ & ++++ \\
\hline
\end{tabular}
1）アセチル CoA カルボキシラーゼ阻害剂
7）微小管重合阻害剤
2）アセ卜乳酸合成酵素阻害剂
8）超長鎖脂肪酸生合成阻害剂
3）光化学系 II 阻害剤
4) 光化学系 I 阻害剂
5）プロトポルフイリノーゲン IX オキシダーゼ阻害剂
6）ヒドロキシフェニルピルビン酸オキシゲナーゼ阻害剤
9）脂質生合成阻害剂
10）オーキシン作用攪乱・阻害剂
(*: 生長阻害率, $-;<19 \%,+; 20-39 \%,++; 40-59 \%,+++; 60-79 \%,++++; 80 \%<$ )
(\#: 引用文献 20 による。 \#\#: 引用文献 13 による。 \#\#\#: 引用文献 12 による。 \#\#\#: 引用文献 5 による) 

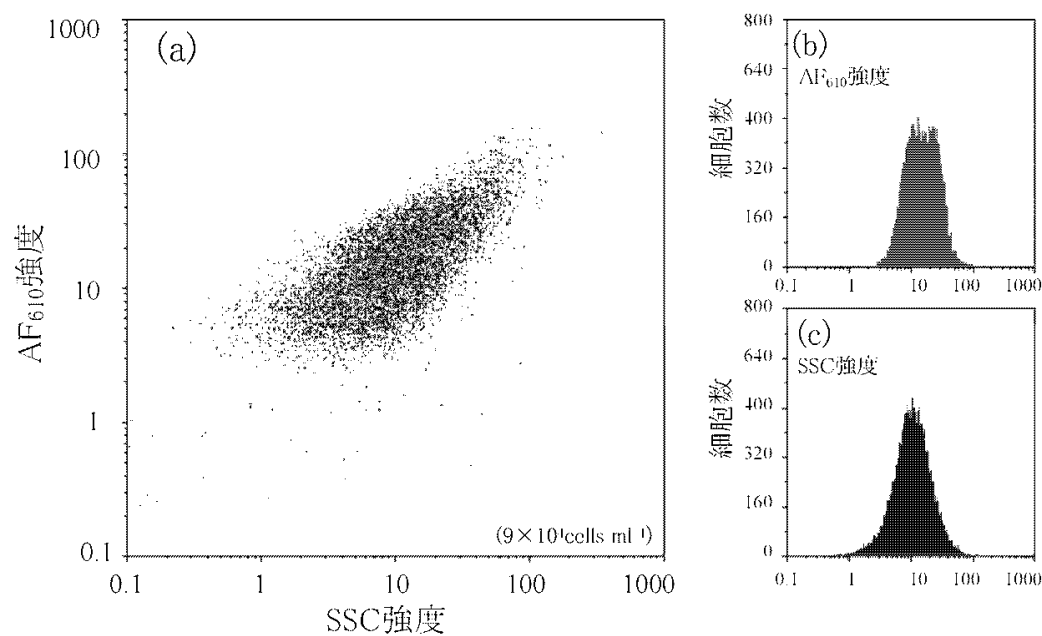

第 1 図 対照区におけるP. subcapitata 細胞群の $\mathrm{AF}_{610}$ 及び SSC 強度のドットプロットとヒストグラム

(a)：ドットプロット図

(b) : $\mathrm{AF}_{610}$ (クロロフィル $\mathrm{a}$ 自家蛍光) 強度のヒストグラム

(c)：SSC (側方散乱光) 強度のヒストグラム

〜 12 倍の濃度9) とした。初期細胞濃度は $1 \times 10^{5}$ cells $\mathrm{ml}^{-1}$ とし, 72 時間前培養して対数増殖期にある細胞 を接種し, 72 時間の暴露を行った。暴露終了後に $P$. subcapitata 細胞を遠心分離 (約 3,000 rpm, $30 \mathrm{~min}$ ) により回収した。この操作を新しい培地を用いて 3 回 繰り返して細胞を洗浄した後, 細胞濃度が $1 \times 10^{4}$ cells $\mathrm{ml}^{-1}$ となるよう調製し, 再び同じ培養条件で培養を続け た。再培養は 13 日間行い，1日毎にフローサイトメー ターで細胞数を計測すると共に, $\mathrm{SSC}$ 強度及び $\mathrm{AF}_{610}$ 強度を測定した。また, 光学顕微鏡で細胞の形態を 観察し, 対照区の観察結果と比較することにより, P. subcapitata細胞の除草剂による影響からの回復性を, 形態及び生長速度の面から評価した。なお,ここでは 暴露区の個体群が対照区と同等の生長速度を示し, フローサイトメーターを用いた測定結果及び光学顕微 鏡による細胞の形態観察結果が対照区と同じ傾向を 示すことを回復と定義した。

\section{結果}

\section{1. 除草剤の 3 種藻類に対する生長阻害率}

40 種類の除草剂 $\left(10 \mathrm{mg}^{-1}\right.$ 溶液もしくは飽和溶 液）の 72 時間暴露による藻類 3 種の生長阻害率を 第 1 表に示した。各藻類の対照区にお打培養 72 時間後の増殖率は, P. subcapitata, M. tenuissima及 びA. minutissimumでそれぞれ 21, 130, 19 倍であっ
た。3 種いずれの藻類に対しても阻害率が低かっ たのは, ジカンバ $(<39 \%)$, ダイムロン $(<39 \%)$ 及 びシハロホップブチル $(<59 \%)$ であった。緑藻 $P$. subcapitataの生長に対しては, これら 3 剂とベンタゾ ン（<19\%） を除く全ての除草剤による阻害率が $80 \%$ を上回った。藍藻 $M$. tenuissimaの生長に対する阻 害率は，上記 3 剂とプレチラクロールを除くVLCFAs （超長鎖脂肪酸生合成）阻害剂 5 剂 $(<59 \%)$ で 低い傾向にあった。一方, 珪藻 A. minutissimumの 生長に対する阻害率は, 上記 3 剂に加えベンタゾ ン $(<19 \%)$, トリフルラリン $(<39 \%)$, ピリブチカルブ $(<39 \%)$, チオベンカルブ $(<59 \%)$ 及びALS（ア セ卜乳酸合成酵素）阻害剂 4 剂（<59\%）で低い傾 向にあった。

\section{2. 除草剤による藻類細胞の形態変化及びその類型 化}

生長阻害下の藻類細胞の $\mathrm{SSC}$ 及び $\mathrm{AF}_{610}$ 強度の 平均值について, 暴露区と対照区の比を除草剤毎に プロットすることにより，除草剤暴露による藻類細胞の 形態変化の程度を評価した（第 2 図）。

藻類 3 種の内, 緑藻 P. subcapitata細胞を用いた 試験で, 暴露した除草剂により SSC 及び $\mathrm{AF}_{610}$ 強度に 大きな差が検出された（第 2 図-a）。その差は SSC, $\mathrm{AF}_{610}$ 強度でそれぞれ, 最大 12,4 倍を超えるもので あった。藍藻 M. tenuissima細胞を用いた試験では, 
除草剂の種類により $\mathrm{AF}_{610}$ 強度に最大で 3 倍程度の 差が検出されたが, SSC 強度に対する影響はほとんど 見られなかった（第 2 図-b)。珪藻 A. minutissimum 細胞を用いた試験では $\mathrm{SSC}, \mathrm{AF}_{610}$ 強度に差が検出 されたが, ほとんどの暴露区で 3 倍以内の差であった (第 2 図-c)。光学顕微鏡による細胞形態の観察で は, SSC 強度が増大している緑藻 P. subcapitataの細 胞群中に, 正常細胞より明らかに肥大している細胞が 観察された。一方, 藍藻 $M$. tenuissima及び珪藻 $A$. minutissimumについては, 光学顕微鏡による観察から 暴露区における細胞の形態変化を判断することはでき なかった。

以上の結果から, 除草剂の影響による細胞の形態 変化は, 緑藻の P. subcapitataで最も容易に観察でき ることが明らかになった。従って, 以降の試験には $P$. subcapitataを用いた。第 3 図に, $\mathrm{SSC}$ 及び $\mathrm{AF}_{610}$ 強 度の相対的な变化と光学顕微鏡により観察される $P$. subcapitata細胞の形態との関係を模式図で示した。

除草剂暴露による緑藻 P. subcapitata細胞の形 態変化について, 暴露区のドットプロットの特徵から 4 型（Type A, B, C, D）に類型化した（第 4 図）。ま た, 試験に使用した除草剤の緑藻P. subcapitata細 胞の形態変化パターンによる分類を第 2 表にまとめた。 Type Aの特徵は, SSC 及び $\mathrm{AF}_{610}$ 強度が増加する細 胞と $\mathrm{AF}_{610}$ 強度が低下する細胞が同時に検出される, すなわち, 光学顕微鏡による観察で肥大した細胞と白 化した細胞の混在が認められることである。Type Aと して 15 種類の除草剤を分類した。これらには HPPD (ヒドロキシフェニルピルビン酸ジオキシゲナーゼ） 阻 害型の 2 剂, 微小管重合阻害型の 3 剂, 脂質生合 成阻害型の 5 剂及びカフェンストロール, ジウロン, ジク ワット, ピペロホス, ピリブチカルブが該当した。Type B の特徵は, $\mathrm{SSC}$ 及び $\mathrm{AF}_{610}$ 強度の両者が若干増加す る細胞が検出されることである。これらの細胞は光学
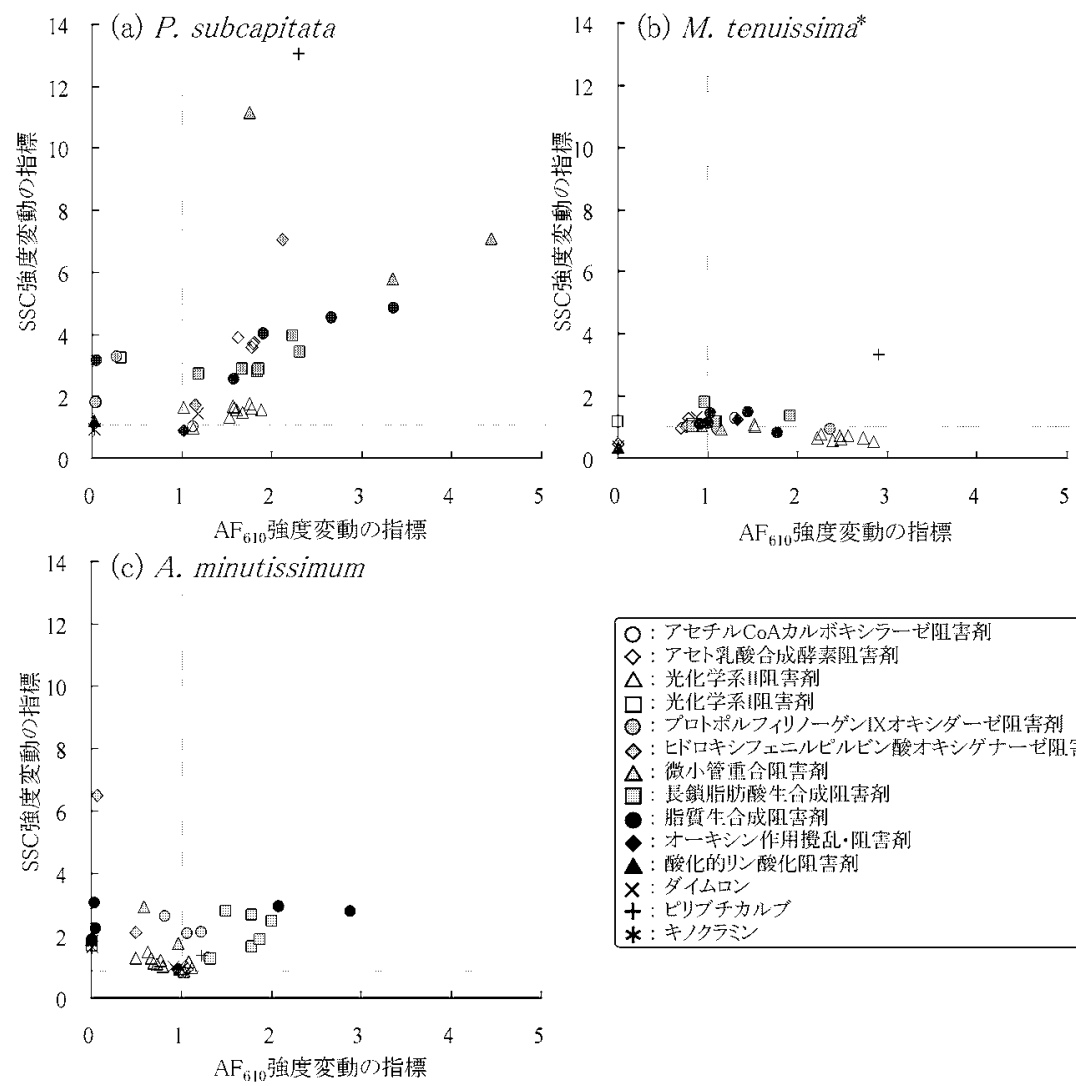

\begin{tabular}{|c|}
\hline 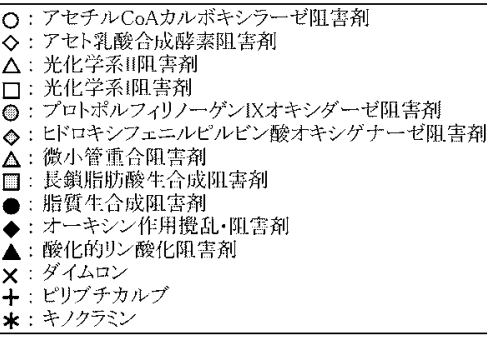 \\
\hline
\end{tabular}

*: H. Lomiswa ;

第 2 図 除草剂暴露によるP. subcapitata, M. tenuissima 及びA. minutissimum の $\mathrm{AF}_{610}$ 及び $\mathrm{SSC}$ 強度の平均值の 変化 (対照区を 1 として作図) 


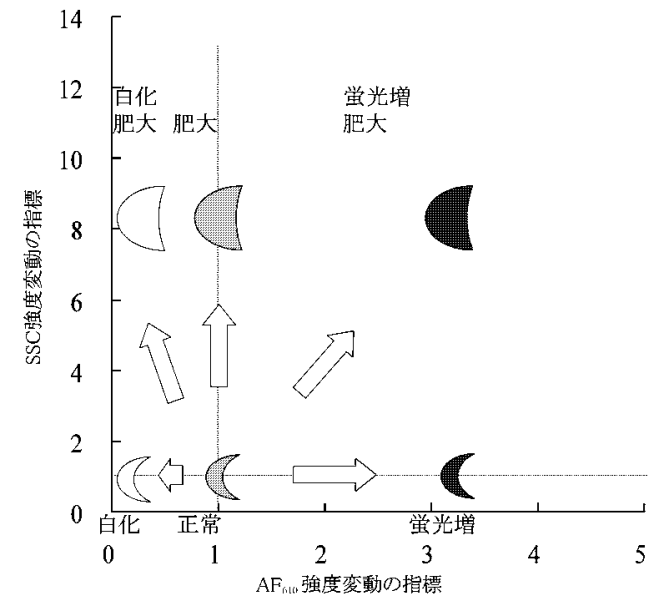

第3 図P. subcapitata を試験生物とした場合におけ る $\mathrm{AF}_{610}$ 及び $\mathrm{SSC}$ 強度の平均值の変動と顕 微鏡観察による形態変化との関連

顕微鏡による観察では対照区との形態の相違を見分 けることができなかった（第 4 図-c）。Type B として 8 種類の除草剤を分類した。これらにはジウロン及びべ ンタゾンを除く光化学系 II 阻害型の除草剤が該当し た。Type $\mathrm{C}$ の特徵は, $\mathrm{SSC}$ 及び $\mathrm{AF}_{610}$ 強度の両者が 増加する細胞が検出されることである。光学顕微鏡に よる観察では肥大した細胞がみられた（第 4 図-d)。 Type Cとして, 8 種類の除草剤を分類した。これらに はALS 阻害型の 4 剤, カフェンストロール及びピペロ ホスを除くVLCFAs 阻害型の 4 片が該当した。Type $\mathrm{D}$ の特徵は, $\mathrm{AF}_{610}$ 強度の低下した細胞が検出される ことである。光学顕微鏡による観察では, 白化した細 胞が多くみられた（第 4 図-e）。Type D として, 5 種 類の除草剂を分類した。これらの除草剂には PPO (プ ロトポルフイリノー゙ン IX オキシダーゼ）阻害型の 3 剂 に加えてキノクラミン及びペンタクロロフェノールが該当 した。なお，本類型化に当てはまらなかった除草剂は ジカンバ, シハロホップブチル, ダイムロン及びベンタゾ ンの 4 剂であり，暴露終了時の細胞のドットプロットは, 対照区と同じ傾向を示した。

\section{3. 除草剤による影響からの藻類細胞の回復性}

除草剂暴露期間及び回復性確認期間に扔ける $P$. subcapitataの生長曲線を第 5 図に示す。除草剤の 暴露濃度は面積法で算出した $\mathrm{EC}_{50}$ の 6 ～12 倍に設 定したが, ベンスルフロンメチル以外の除草剤につい ては, この濃度における暴露でほぼ完全に生長が阻 害された。緑藻 P. subcapitata細胞の除草剂による影
響からの回復性は, 光化学系 II 阻害剤であるシメリン （Type B）及び ALS 阻害剤であるベンスルフロンメチ ル（Type C）で高く, 除草剤を含まない再培養におい て, 対照区と変わらない生長速度を示した。VLCFAs 阻害型のプレチラクロール及びメフェナセッ（Type C） と脂質生合成阻害型のエスプロカルブ及びチオベンカ ルブ（Type A）は再培養 6〜 7 日後に対照区と変わ らない生長速度を示した。キノクラミン（Type D）を暴 露した区では回復が遅く, 対照区と変わらない生長速 度を示したのは 11 日後であった。

いずれの試験区においても，回復性試験終了時の 細胞のドットプロットは対照区と同じ傾向を示した。また, 光学顕微鏡による観察においても, 細胞の形態は対照 区と同様であることを確認した。

\section{考察}

\section{1. 除草剤による藻類細胞の形態変化及びその類型 化}

本研究では藻類 3 種について除草剂暴露による細 胞の形態変化を調査したが, 藍藻 $M$. tenuissima及び 珪藻 A. minutissimumについては, 光学顕微鏡による 観察から細胞の形態変化を判断することが困難であっ た。その要因として, 藍藻 M. tenuissimaについては, 細胞直径が $1.3 \sim 2.0 \mu \mathrm{m}$ と非常に小型なため ${ }^{8)}$, 光 学顕微鏡による観察では形態変化を認識できなかった ものと思われる。また, 珪藻 A. minutissimumについて は細胞膜の外側に硬い珪酸質の被殼を有するため, 硬い細胞壁を有しない緑藻よりも形態変化が起こりにく いと推察された。

P. subcapitata細胞の観察には, 光学顕微鏡に加え 蛍光顕微鏡を使用したが, 正常な細胞からは青色光 による励起で赤色の自家蛍光が観察される一方, 白化 した細胞からは赤色の自家蛍光はほとんど観察されな かった（第 4 図-b)。この結果より, $\mathrm{AF}_{610}$ 強度の低下 した細胞は白化した細胞に相当すると考えられた。ま た, P. subcapitata細胞の場合, SSC 強度は細胞の大 きさと対応しており, SSC 強度の増加した細胞は肥大 した細胞に相当すると考えられた。

除草剂暴露による緑藻 P. subcapitata細胞の形態 変化の傾向を,ドットフロットの特徵から類型化し, 作用 機構との関連を検討したところ, ジウロン, カフェンスト ロール及びピペロホスについて形態変化と作用機構の 傾向が一致しなかった。ジウロンは光化学系 II 阻害 型の除草剂とされているが, その他の光化学系 II 阻 

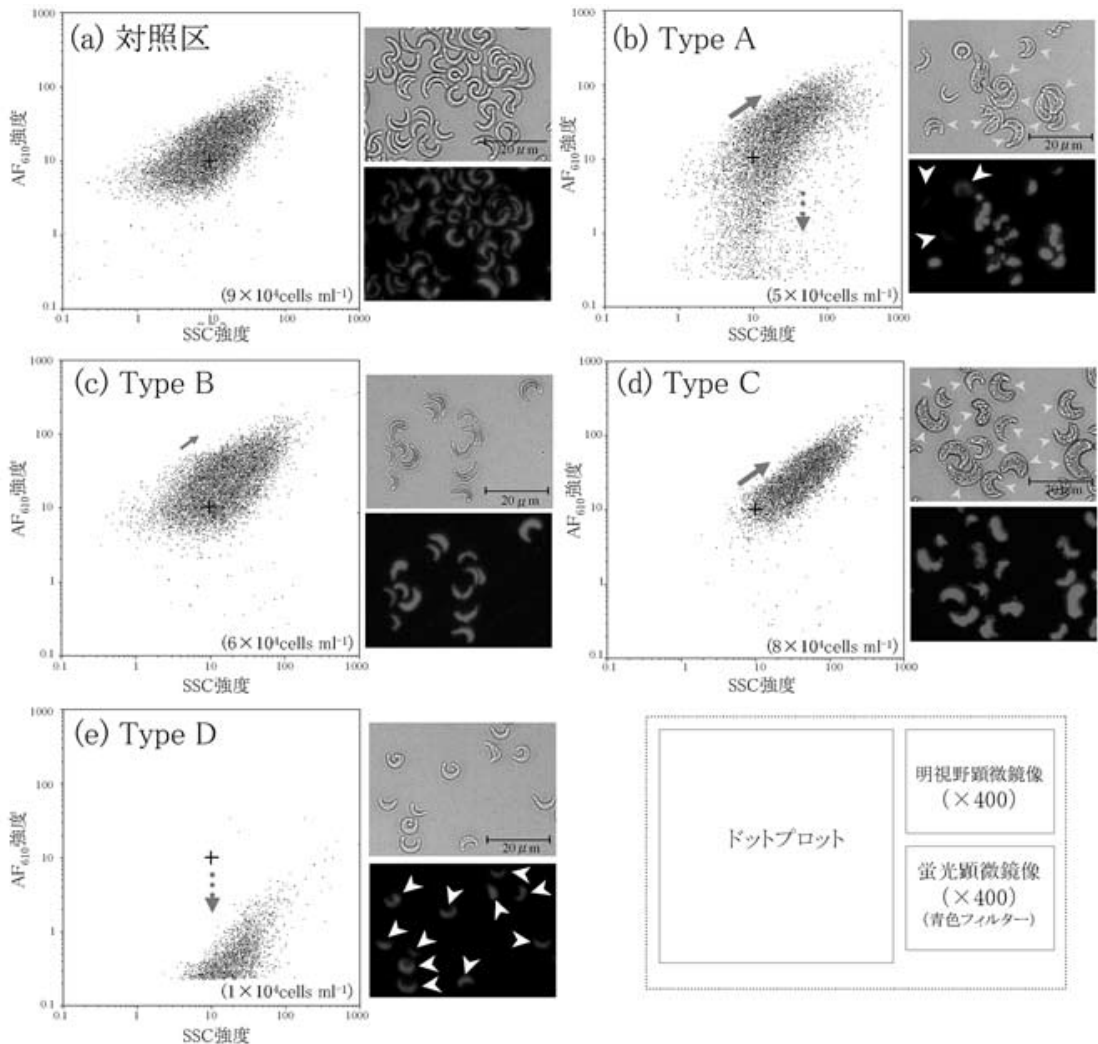

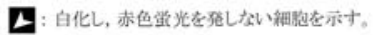

四: 肥大した紼胞を示才。

第 4 図除草剂暴露によるP. subcapitata 細胞の形態変化の類型化

(a)：対照区

(b) : Type A ; チオベンカルブ暴露区

(c) : Type B ; シメトリン暴露区

(d): Type C ; ベンスルフロンメチル暴露区

(e) : Type D ; キノクラミン暴露区

暴露 72 時間後の細胞を計測・観察, 暴露濃度は $10 \mathrm{mg} \mathrm{l}^{-1}$ もしくは飽和濃度

光学顕微鏡写真と蛍光顕微鏡写真は同サンプルを観察したものであり対応している

害型の除草剂が示す形態変化の傾向と異なり, $\mathrm{AF}_{610}$ 強度の低下する細胞が検出された。このことから, ジ ウロンは光化学系 II 阻害以外の作用を有する可能 性が示された。また, カフェンストロール及びピペロホス はVLCFAs 阻害型除草剂とされているが, その他の VLCFAs 阻害型除草剂が示す形態変化の傾向と異 なり, $\mathrm{AF}_{610}$ 強度の低下する細胞が検出された。この 結果は, カフェンストロール及びピペロホスが VLCFAs 阻害以外の作用を有する可能性を示すものである。し かしながら, 本研究では全ての供試除草剤について, $10 \mathrm{mg} \mathrm{l}^{-1}$ または飽和濃度で暴露を行っているため, 供 試除草剂によっては暴露濃度が高く, 一次作用点以
外の作用点にも影響している可能性は否定できない。 形態変化の傾向を精緻に類型化するには, 各除草剂 の影響濃度を明らかにし，一次作用点のみが反応す る濃度で暴露して形態変化の傾向を比較する必要が あると考えられた。

類型間における形態変化の程度については, 肥 大した細胞の観察されたType A 及び Cにおける発 生頻度を比較すると Type C > Type A となり, 同様に, 白化した細胞の発生頻度は Type D>Type A となっ た (第 4 図)。本結果は, 藻類細胞の形態変化から 除草剂の作用機構を類推できる可能性を示している。 一方, 形態変化の傾向のみから毒性の強弱を評価す 
第 2 表 試験に使用した除草剤の緑藻 P. subcapitata 細胞の形態変化パターンによる分類（10 $\mathrm{mg}^{1^{-1}}$ もくは飽和 濃度で暴露)

\begin{tabular}{|c|c|}
\hline 形態変化パターン & 除草 剂 \\
\hline Type A & $\begin{array}{l}\text { アミプロホスメチル, エスプロカルブ, カフェンストロール, ジウロン, ジクワット, } \\
\text { ジメピペレート, チオベンカルブ, トリフルラリン, ピペロホス, ピラゾキシフェン, } \\
\text { ピラゾレート, ピリブチカルブ, ベンスリド, ペンディメタリン, モリネート }\end{array}$ \\
\hline Type B & $\begin{array}{l}\text { アトラジン， シアナジン， シマジン， ジメタメトリン， シメトリン， プロパニル， } \\
\text { プロメトリン，リニュロン }\end{array}$ \\
\hline Type C & $\begin{array}{l}\text { アジムスルフロン, アラクロール, イマゾスルフロン , ピラゾスルフロンエチル, } \\
\text { プレチラクロール, ベンスルフロンメチル , メトラクロール, メフェナセット }\end{array}$ \\
\hline
\end{tabular}

Type D オキサジアゾン, キノクラミン, ビフェノックス, ペンタクロロフェノール, ペントキサゾン

変化なし ジカンバ, シハロホップブチル, ダイムロン, ベンタゾン

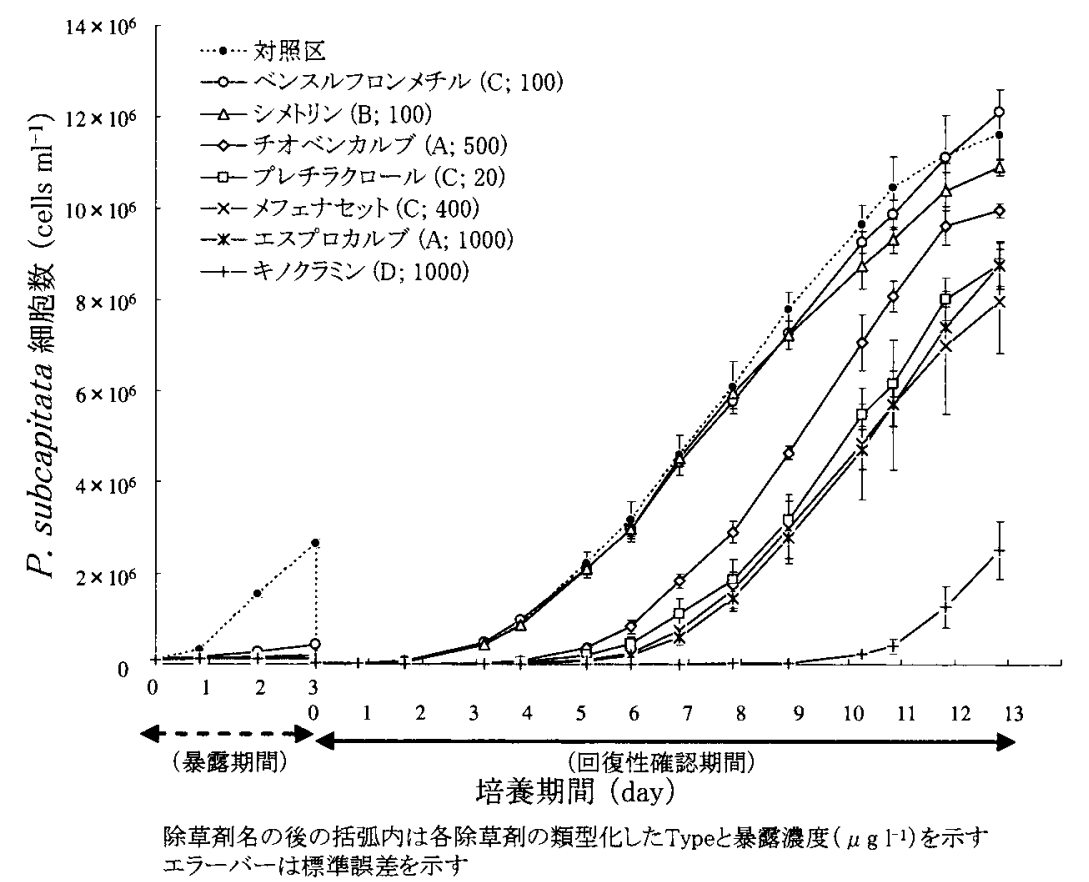

第 5 図 除草剤暴露期間及び回復性確認期間における P. subcapitata の生長曲線

ることは困難であるため, 本評価は藻類の個体群に及 ぼす定性的な変化の評価に限られる。

\section{2. 除草剤による影響からの藻類細胞の回復性}

P. subcapitata細胞に 7 種類の除草剂を 72 時間暴 露し, その後除草剂を含まない条件で再培養を行った 場合, すべての暴露区で, 除草剤による影響からの回 復性が確認された。この結果より,これらの除草剤が
$10 \mathrm{mg} \mathrm{l}^{-1}$ もしくは飽和濃度での短期間（72 時間）の 暴露によって緑藻 P. subcapitata細胞に対し影響を与 えたとしても, 影響は可逆的で, 個体群に対して長期 的な影響を及ぼす危険性は低いと考えられた。72 時 間を超える長期間の暴露では, 短期の暴露では殺藻 的な作用が表れない除草㓱（酸アミド系, スルホニル ウレア系及びトリアジン系除草剤）でも二次的な作用 
が表れる可能性もあり，除草剤による影響からの回復 性に影響を及ぼす可能性は否定できない。また, 殺藻 的な作用を有する除草剂（カーバメート系除草棛及び キノクラミン）では, 長期間の暴露ではすべての細胞 が死亡し, フラスコ内という閉鎖的な環境では回復性を 示さなくなることも予測されるが, 野外環境において除 草剂の影響で微細藻類が回復不能なほど死滅する危 険性は極めて低いと考えられた。

除草剂暴露による形態変化と回復性との関係を 考察すると, 白化した細胞が多く観察されたキノクラミ ン（Type D）暴露区で回復までの期間が長く, 一部 白化した細胞が観察された脂質生合成阻害剤（エス プロカルブ及びチオベンカルブ； Type A）及び肥大し た細胞が多く観察されたVLCFAs 阻害剤（プレチラ クロール，及びメフェナセット；Type C）の暴露区では 対照区と比べると 3 ～日遅れて回復がみられた。一 方, 細胞の肥大が観察された ALS 阻害剂であるべン スルフロンメチル（Type C）暴露区及び形態にほとん ど変化を生じなかった光化学系 II 阻害剂のシメトリン (Type B）暴露区では回復までの期間が短く, これら の剂による生長阻害下の細胞は, 対照区と同等の増 殖力を有していた（第 5 図）。この結果は, 作用機構 に関する情報とフローサイトメリー解析の結果を基に, 除草剂の影響からの回復性の程度を推測できることを 示唆している。

従来の藻類生長阻害試験では, 藻類細胞数の計 測に主として粒子計測計や血球計算計等が用いられ ている。しかし, これらの機器を用いた細胞の計測は, 生死の判別ができない, 非生物的粒子を同時に計測 してしまう, 毒性の作用機構に関する情報が得られない 等の欠点が指摘されている ${ }^{19}$ 。フコーサイトメトリーを利 用して細胞を計測する方法は, これらの久点を克服し うる手法として期待されている。また, 土壤等無機粒 子と共存した試験")や複数種の藻類を混合した試験の 等, 新たな試験手法開発に活用されている。

本研究では, $\mathrm{SSC}$ 及び $\mathrm{AF}_{610}$ 強度を測定項目とし て, フローサイトメトリー解析により除草剂が藻類細胞に 及ぼす影響の評価を行った。本測定項目に加え FDA (Fluorescein Diacetate) による生細胞染色や前方散 乱光による細胞の大きさの測定等の測定項目を追加す ることにより,より詳細な評価が行えるものと期待される。 また, 高次の影響評価では, 影響からの回復性や個 体群に対する影響の可逆性に関する評価が必要とな る。本研究で示したフローサイトメトリー解析による除
草剂の微細藻類細胞に対する影響評価法は, これら の研究·開発に資するものと考えられる。

\section{引用文献}

1) Adams, M.S., J.L. Stauber, 2004. Development of a whole-sediment toxicity test using a benthic marine microalga. Environ. Toxicol. Chem. 23, 1957-1968.

2) Berglund, D.L. and S. Eversman 1988. Flow cytometric measurement of pollutant stresses on algal cells. Cytometry 9, 150-155.

3) Chisholm, S.W., R.J. Olson, E.R. Zettler, R. Goericke, J. Waterbury and N. Welschmeyer 1988. A novel free living prochlorophyte abundant in the oceanic euphotic zone. Nature 334, 340-343.

4) Cid, A., P. Fidalgo, C. Herrero and J. Abalde, 1995. Flow cytometry determination of acute physiological changes in a marine diatom stressed by copper. Microbiologia. 11, 455-460.

5)（独）農業・生物系特定産業技術研究機構, 最新 農業技術辞典.

6) Franklin, N.M., J.L. Stauber and R.P. Lim, 2004. Development of multispecies algal bioassays using flow cytometry. Environ. Toxicol. Chem. 23, 1452-1462.

7) Franqueira, D., M. Orosa, E. Torres, C. Herrero C. and A.

Cid, 2000. Potential use of flow cytometry in toxicity studies with microalgae. Sci. Total Environ. 247, 119-126.

8）廣瀬弘幸, 山岸高旺 1977. 日本淡水藻図鑑, 内田 老鶴圃. 東京. p. 39.

9) Ishihara, S., T. Horio, Y. Kobara, A Yokoyama and M. Ueji (投稿準備中) The sensitivity of four unicellular algae to rice herbicides.

10) ISO 1989. Water quality-Fresh water algal growth inhibition test with Scenedesmus subspicatus and Selenastrum capriconutum, ISO8692.

11）中内啓光 2004. 「新版フローサイトメトリー自由 自在」. 秀潤社. 東京.

12）日本植物防疫協会 2001. 農薬ハンドブック 2001 年版. 日本植物防疫協会. 東京. 711-766.

13）日本植物防疫協会 2005. 農薬ハンドブック 2005 年版. 日本植物防疫協会. 東京. 476-679.

14) OECD 1984. Alga, growth inhibition test, OECD guidelines for the testing of chemicals 201.

15) Reiriz, S., A. Cid, E. Torres, J. Abalde and C. Herrero, 1994. Different responses of the marine diatom Phaeodactylum tricornutum to copper toxicity. Microbiologia. 10, 263-72.

16) Rioboo, C.O. Gonzalez, C. Herrero and A. Cid, 2002. Physiological response of freshwater microalga (Chlorella vulgaris) to triazine and phenylurea 
herbicides. Aquat Toxicol. 59, 225-35.

17) Saroja, G and B. Salil 1982. Effects of methyl parathion on the growth, cell size, pigment and protein content of Chlorella protothecoides. Environ. Pollut. Ser. A. 27. 297-308.

18）園池公毅 2005. パルス変調クロロフィル蛍光測 定におけるデー夕の解釈, 日本光合成研究会会報 42, 7-12.

19) Stauber, J.L., N.M. Franklin and M.S. Adams, 2002. Applications of flow cytometry to ecotoxicity testing using microalgae. Trends Biotechnol. 20, 141-143.

20) The British Crop Protection Council 2001. The pesticide manual twelfth edition.

21) Troussellier, M., C. Courties and A. Vaquer, 1993. Recent applications of flow cytometry in aquatic microbial ecology. Biol. Cell. 78, 111-121.

22) U.S. EPA 1996. Ecological effects test guidelines ; Algal toxicity Tiers I and II, OPPTS 850. 5400.

23）（財）地球・人間環境フォーラム 1997. GEF 保存 株リスト'97, 19-27.

\section{Evaluation of herbicide effects on micro algal cells by flow cytometric analysis}

\author{
Satoru Ishihara *, Takeshi Horio * , Yuso Kobara * \\ and Atsushi Yokoyama*
}

\section{Summary}

The effects of forty herbicides on cell morphologies of the freshwater microalgae such as Pseudokirchneriella subcapitata (green alga), Achnanthidium minutissimum (diatom) and Merismopedia tenuissima (blue green alga) were investigated by microscopic observation, measuring side scatter (SSC) intensity and autonomous fluorescence $\left(\mathrm{AF}_{610}\right)$ of chlorophyll a using a flow cytometry. Morphological changes and differences in chlorophyll a amount of these microalgae were induced by the exposures to high concentration (10 $\mathrm{mg} \mathrm{l}^{-1}$ or water solubility) of herbicides. Especially, the responses on cell shape of $P$. subcapitata were greater than those of two other species and these reactions observed in $P$. subcapitata were classified into four types.

The cell volumes were greatly increased at the highest concentrations ( 6 to 12 times density of $72 \mathrm{~h}-\mathrm{EC}_{50}$ ) of the five herbicides (bensulfuronmethyl, esprocarb, mefenacet, pretilachlor, and thiobencarb) and the blanching cells were observed in incubations with three herbicides (esprocarb, quinoclamine and thiobencarb). The recoverability from morphological changes of $P$. subcapitata cells was confirmed in exposure experiments with seven kinds of herbicides (bensulfuronmethyl, esprocarb, mefenacet, pretilachlor, quinoclamine, simetryn and thiobencarb). It is clear that every treated $P$. subcapitata population did not extinct in a short time (72h) exposures of high concentration of seven herbicides, and that the recoverability of $P$. subcapitata population is apt to decline with increasing the amount of blanching cells.

\footnotetext{
* National Institute for Agro-Environmental Sciences (NIAES), 3-1-3 Kannondai, Tsukuba, Ibaraki 305-8604, Japan satorui@niaes.affrc.go.jp
} 